\title{
Percoll Density Gradient Centrifugation of Rat Pituitary Tumor Cells: a Study of Functional Heterogeneity Within and Between Tumors With Respect to Growth Rates, Prolactin Production and Responsiveness to the Somatostatin Analog SMS 201-995
}

\author{
LEO J. HOFLAND, PETER M. VAN KOETSVELD and STEVEN W. LAMBERTS
}

Department of Medicine, Erasmus Liniversity, the Netherlands

\begin{abstract}
Tumor cells prepared from PRL-secteliny ral piluitary $7315 b$ tumors of increasing weight were separated on continuous Percoll density gradients, according to differences in their density. Whether the cell subpopulations obtained by density gradient separation shou'ed differences in protein content per cell, PRL production per cell, growth rates and responsizeness to the somatostatin analog SMS 201-995 in vitro was investigated. In addition, ice siudied PRL release by individual $7315 b$ tumor cells, using the reverse hemolytic plaque assay (RHPA)

The tumor cells from tumors of increasing weight were recovered within a narrow density range $(1.060-1.070 \mathrm{~g} / \mathrm{ml})$ and showed a normal distribution profle. There were no differences between the subpopulations with respect to the parameters mentioned above. Moreover, no differences zere found with respect to these parameters between tumor cells derived from tumors of increasing weight. In agreement with the above data we found no evidence for subtypes of adenoma cells being preferentially responsive to SMS 201-995, using the RHPA. Conclusions: (1) the transplantable PRL-secreting rat pituitary tumor $7315 b$ consists of a functionally homogeneous cell population; (2) growth of this tumor in vivo does not lead to the induction of functionally heterogeneous cell subpopulations within this tumor; (3) the escape of this tumor from the tumor growth-inhibitory effect of SMS 201-995, which has previously been demonstrated in vivo, may not have heen the result of clonal selection of somatostatin-unresponsize cells.
\end{abstract}

\section{INTRODUCTION}

Most murine and human solid tumors show intratumor heterogeneity. Tumor cell populations can be heterogeneous for many phenotypic characteristics such as karyotype, biochemical profile (c.g. levels of various enzymes), hormone receptor content and drug or radiosensitivity [1]. Little is known, however, with respect to functional heterogeneity within pituitary tumors. Although it has been demonstrated that both human and rat pituitary tumors may consist of subpopulations of cells secreting more than one hormone simultaneously $[2-7]$, a possible differential responsiveness of these tumor

Accepted 14 September 1989

Correspondence and requests for reprints to: Leo J. Hofland, Department of Medicine III. University Hospital Dijkzigt, 40 Dr. Molewaterplein. 3015 G1) Rotterdam, the Netherlands. cell subpopulations to hypothalamic regulatory hormones or to drugs has not been investigated extensively. In addition, it is not known whether, when cell proliferation occurs in vitro, all cells within a pituitary tumor cell suspension show similar growth rates. A knowledge of the intratumor heterogeneity of pituitary tumors can bc helpful in the understanding of the effects of certain drugs on the growth of the tumor cells or on the regulation of hormone release by these tumor cells in vivo and in vitro. The somatostatin analog SMS 201-995 has previously shown to inhibit the growth of the transplantable prolactin (PRL)-secreting rat pituitary tumor $7315 \mathrm{a}$ in vivo [8]. However, this tumor rapidly 'escaped' from the tumor growth-inhibitory effect of SMS 201-995. In this study [8], one could not unequivocally exclude the possibility that this 'escape' 
might have been due to clonal selection of somatostatin-unresponsive tumor cells.

The aim of the present study was to investigate whether functional heterogeneity exists within and betwcen $7315 \mathrm{~b}$ PRL-secreting rat pituitary tumors of increasing weight. For this purpose we used Percoll density gradient centrifugation of acutely dispersed $7315 \mathrm{~b}$ tumor cells in order to obtain subpopulations of tumor cells with different densities. The study investigated whether the subpopulations of tumor cells differed in (a) growth rates, (b) protein and PRL content of the cells and (c) responsiveness of the tumor cells to the inhibitory effect of the somatostatin analog SMS 201-995. Since pituitary tumor cells do not store large amounts of hormone and because the density of the cells may be dependent on the mass of protein hormone present in the cytoplasm [9], the method of density gradient separation may not be an appropriate method for the study of functional heterogeneity among cells of the $7315 \mathrm{~b}$ tumor with respect to PRL release. Therefore, we also investigated PRL release by $7315 \mathrm{~b}$ tumor cells at the single cell level, using the reverse hemolytic plaque assay (RHPA) $[10]$.

\section{MATERIALS AND METHODS}

Animals, tumor growth in vivo and preparation of dispersed tumor cells

The origin of the transplantable PRL-secreting $7315 \mathrm{~b}$ rat pituitary tumor is described in detail elsewhere [11]. This tumor originated from the ACTH-PRL-secreting 7315a tumor but has lost its ability to secrete ACTH as well as its receptors for glucocorticoids. It is unchanged with respect to PRL secretion, and estrogen and progesterone receptor content [11]. Female buffalo rats (Harlan, Madison, U.S.A.) weighing 160-180 g were inoculated subcutaneously between the scapulae with $0.2 \mathrm{ml}$ of a suspension of the $7315 \mathrm{~b}$ tumor. This suspension was prepared by mincing $20 \mathrm{~g}$ of tumor tissue in $50 \mathrm{ml}$ sterile saline $(9 \mathrm{~g} \mathrm{NaCl} / 1)$. The rats were kept in an artificially illuminated room (09.00-21.00 h) with food and water ad libilum. Two, 3 and 4 weeks after inoculation of the tumor cell suspension, rats were killed by an overdose of ether anesthesia and tumors of 7, 11 and $40 \mathrm{~g}$ were removed and collected in sterile saline.

The $7315 \mathrm{~b}$ pituitary tumor cells were isolated by mechanical dispersion as described in detail elsewhere [11]. The viability of the resulting cell suspension was always greater than $90 \%$. The cells were resuspended either in culture medium (for culture of the original, unfractionated cell suspension) or in Hank's balanced salt solution (HBSS) supplemented with $10 \mathrm{~g} / \mathrm{l}$ human serum albumin (HSA), penicillin ( $\left.10^{5} \mathrm{U} / \mathrm{l}\right)$, streptomycin (100 mg/ 1), fungizone $(0.5 \mathrm{mg} / \mathrm{l})$ and sodium bicarbonate
$(0.4 \mathrm{~g} / 1)$. The latter cell suspension was used for Percoll gradient separation.

\section{Separation of dispersed cells on continuous Percoll density gradients}

A 90\% Percoll solution was made by mixing nine parts of Percoll stock solution (Pharmacia Fine Chemicals Uppsala, Sweden) with one part of a 10 times concentratcd calcium- and magnesiumfree Hank's balanced salt solution (Gibco, Europe). This $90 \%$ iso-osmotic Percoll solution was further diluted to $50 \%$ (density $1.070 \mathrm{~g} / \mathrm{ml}$ ) with phosphate buffered saline ( $\mathrm{pH} 7.4$ ). Eight milliliters of the $50 \%$ Percoll solution were then added to polypropylene tubes (Sorvall; $12 \mathrm{ml}, 16 \times 102 \mathrm{~mm}$ ). To one tube, which was treated the same as all other tubes, calibration density marker beads (Nos 2-9, Pharmacia, Uppsala, Sweden) were added. Gradients were pre-formed by centrifugation at $25,300 \mathrm{~g}$ in a Sorvall SS-34 rotor during $30 \mathrm{~min}$ at $20^{\circ} \mathrm{C}$. For cell separation, approximately $1.5 \times 10^{7}$ to $2 \times 10^{7}$ cells in $2 \mathrm{ml} \mathrm{HBSS}+$ HSA were layered on the preformed gradients and then centrifuged at $800 \mathrm{~g}$ during $20 \mathrm{~min}$ at $20^{\circ} \mathrm{C}$. The gradients were fractionated using an Auto Densi-Flow II C (Searle, Bachler Instruments, Fort Lee, New Jersey, U.S.A.; US Pat. No. 3682305). Twelve fractions $(833 \mu l$ per fraction) were collected from the top of the gradients. Each fraction was then diluted (twice) with HBSS + HSA and centrifuged for $5 \mathrm{~min}$ at $600 \mathrm{~g}$. The cells were washed twice more with $\mathrm{HBSS}+\mathrm{HSA}$ and finally resuspended in culture medium (see below). The counting of the cells in each fraction was done with a Bürker counter chamber. The viability of the cells was determined by trypan blue exclusion.

After centrifugation, calibration of the formed density gradients was done by measuring the distance of each density marker bead to the meniscus of the Percoll fluid. Cell recovery from the gradients yielded $86 \pm 8 \%$ (mean \pm S.E.; $n=3$ independent experiments).

\section{Cell culture}

The culture medium used in all experiments is minimal essential medium with Earle's salts (MEM) supplemented with MEM non-essential amino acids, sodium pyruvatc $(1 \mathrm{mmol} / \mathrm{l}), 10 \%$ fctal calf serum (FCS), penicillin $\left(10^{5} \mathrm{U} / \mathrm{l}\right)$, streptomycin (100 $\mathrm{mg} / \mathrm{l})$, fungizone $(0.5 \mathrm{mg} / \mathrm{l})$, I.-glutamine $(2 \mathrm{mmol} / \mathrm{l})$ and sodium bicarbonate $(2.2 \mathrm{~g} / \mathrm{l}$ final concentration). The medium was adjusted to $\mathrm{pH} 7.4$ with $1 \mathrm{~mol} / \mathrm{l} \mathrm{NaOH}$. The $7315 \mathrm{~b}$ pituitary tumor cells were seeded at a density of 25,000 viable cells per well in $1 \mathrm{ml}$ of culture medium in 24-well plates (Costar, Cambridge, Massachusetts, U.S.A.) without or with SMS 201-995. After 6 days of culture the media and cells were collected and stored 
at $-20^{\circ} \mathrm{C}$ until analysis. Medium and supplements were purchased from Grand Island Biological Co. Europe (Paisley, U.K.). SMS 201-995 was a gift from Sandoz (Basel, Switzerland).

\section{Reverse hemolytic plaque assay (RHPA)}

The reverse hemolytic plaque assay was performed as described in detail elsewhere [10]. In short, freshly dispersed (unseparated) and 6-day cultured cells (which had not attached to the floor of the wclls) were harvested, centrifuged and resuspended in MEM $+0.1 \%$ bovine serum albumin (BSA; Sigma). A suspension of 150,000 cells $/ \mathrm{ml}$ was mixed with an equal volume of a $12 \%$ suspension of protein A-coated ovine red blood cells (oRBC). This cell mixture was infused into Cunningham chambers, which were prepared on poly-L-lysine-coated glass slides. After $1 \mathrm{~h}$ of incubation at $37^{\circ} \mathrm{C}$ in a $\mathrm{CO}_{2}$ incubator the chambers were rinsed twice with MEM + BSA. Thereafter, incubations were started by infusing rabbit anti-rat PRL serum (1:50 final dilution in MEM + BSA) without or with $10 \mathrm{nmol} /$ I SMS 201-995. The anti-rat PRL serum was a kind gift of Dr D.A. Leong (University of Virginia, Charlottesville, U.S.A.). The specificity of this antiserum was described previously in detail [12]. After $24 \mathrm{~h}$ of incubation at $37^{\circ} \mathrm{C}$ in the $\mathrm{CO}_{2}$ incubator the chambers were filled with immunoglobulinstripped guinea pig complement [12] at a dilution of 1:20 in MEM + BSA. The choice of an incubation time of $24 \mathrm{~h}$ was based on several experiments using increasing incubation times (not shown).

After $45 \mathrm{~min}$ of incubation with complement, during which time plaque formation occurred, the reaction was stopped by infusing fixative ( $2 \%$ glutaraldehyde in phosphate-buffered saline, $\mathrm{pH}$ 7.4). The $7315 \mathrm{~b}$ cells were stained with hematoxylin in order to ensure the detection of non-plaque forming cells. All incubations were performed on duplicate slides and 100 cells per slide were counted. Plaque areas were measured with a calibrated ocular micrometer. A Leitz Diavert microscope was used at 400-fold magnification.

Assays

Rat PRL concentrations in the culture media were measured by a double antibody RIA using materials and protocols supplied by the distribution officer of the NIADDK. All results are expressed in rat PRL refercnce preparation (RP-1).

The DNA content of the tumor cells was determined as described in detail elsewhere [13]. The method is based on a DNA-dependent fluorescence enhancement of a fluorochrome. In short, freshly isolated tumor cells $(25,000$ cells $)$ or the cultured tumor cells at the end of the incubation period (which did not attach to the floor of the wells) were collected and washed twice with an ice-cold saline solution. The remaining cell pellet was stored at $-20^{\circ} \mathrm{C}$ until analysis. The cells were extracted with $300 \mu \mathrm{l}$ ammonia solution $(1 \mathrm{~mol} / \mathrm{l})-$ Triton $\times 100$ $(0.2 \% \mathrm{v} / \mathrm{v})$ by sonification during $5 \mathrm{~s}$ at amplitude 15 (Soniprep 150; MSE). Thereafter 2 ml assay buffer $(100 \mathrm{mmol} / \mathrm{l} \mathrm{NaCl}, 10 \mathrm{mmol} / \mathrm{l}$ EDTA, $10 \mathrm{mmol} / \mathrm{l}$ Tris; $\mathrm{pH} 7.0$ ) was added. The remaining solution was centrifuged at $2000 \mathrm{~g}$ during $5 \mathrm{~min}$ and $100 \mu \mathrm{l}$ aliquots of the supernatant was mixed with $1.5 \mathrm{ml}$ Hoechst dye $\mathrm{H} 33258(100 \mu \mathrm{g} / \mathrm{l})$. Fluorescence was measured after $15 \mathrm{~min}$ with the excitation and emission wavelengths set at 350 and $455 \mathrm{nM}$ respectively. The fluorescence of experimental samples was referenced to a standard curve of calf thymus DNA (type II, no D-3636; Sigma Chemical Company, St Louis, MO, U.S.A.).

The protein content of the tumor cells was estimated using the reagent kit from Bio-Rad (Richmond. CA) with BSA (Sigma) as standard. For estimation of the protein content of the cells the same cell extracts were used as those used for DNA determination.

\section{Analysis of data}

The statistical significance of the differences between mean values was determined using oneway analysis of variance (ANOVA). When significant overall effects were obtained by ANOVA, multiple comparisons were made using the Newman-Keuls test [14]. All data are expressed as mean \pm S.E.M. We considered a difference between mean values to be statistically significant when $P<0.01$ because each experiment which is presented represents a single experiment.

'Growth rates' of the cells were calculated as follows: the number of doublings in $144 \mathrm{~h}$ is $b-a$ in which $a=\log _{2}$ (DNA $t=0 \mathrm{~h}$ ) and $b=\log _{2}$ (DNA $t=144 \mathrm{~h}$ ). This method of calculation of the growth rate of cells has been previously described by Patterson [15].

\section{RESULTS}

Figure 1 shows the distribution of the recovered viable cells after separation of $7315 \mathrm{~b}$ tumor cell suspensions derived from tumors of increasing weight on continuous Percoll density gradients. In the figure the density profiles of the gradients are also indicated. The profiles of the recovered cells from the different tumors were completely similar in that they all showed a normal distribution with the majority of the cells being recovered in a narrow density range between densitics of 1.060 and $1.070 \mathrm{~g} / \mathrm{ml}$. Since in the fractions $4-6$ and $9-11$ not enough cells were recovered in order to perform culture studies, we used pooled fractions. With these pooled fractions the experiments as described below were performed. The pools are indicated in Fig. 1 by I, II and III on the $x$-ordinate. 

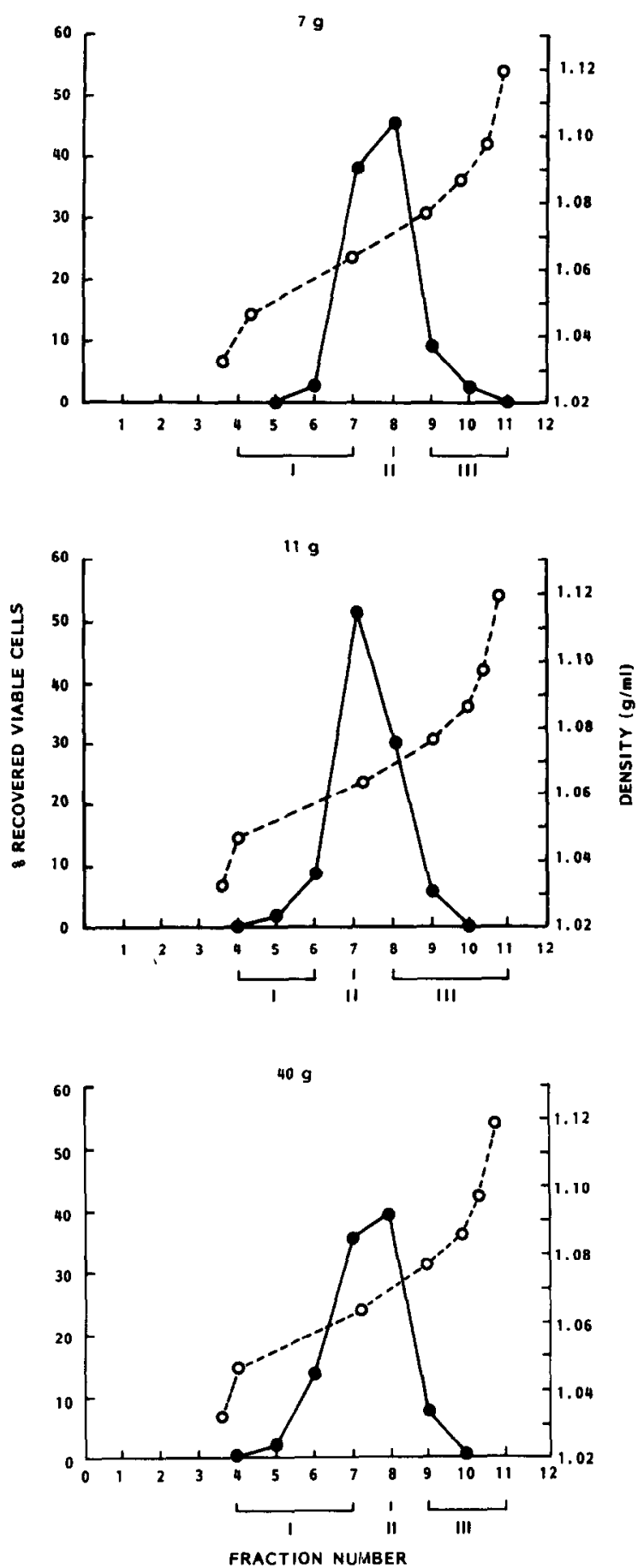

Fig. 1. Profiles of recovered viable cells in the gradient fractions after separation of $7315 b$ tumor cells derived from tumors of increasing weight $(7,11$ and $40 \mathrm{~g})$ on continuous Percoll density gradients $(-)$. The density profile of the Percoll gradient is indicated by the interrupted line (O---O). Each point on this density profile represents the position of density marker beads each having a specific density in the gradient. The symbols $I, I I$ and III which are indicated on the $\mathrm{x}$-ordinate represent the pooled fractions that were used in the 6-day culture studies (pool I, II and III cells).

In none of the tumors were there statistically significant differences in the amount of protein per ng DNA between pool I, II and III cells. This is shown in Table 1. In addition we found no statistically significant difference of protein per
DNA between the tumors of different weight (Table 1).

Table 2 shows that the amount of DNA significantly increases from $t=0$ to $t=144 \mathrm{~h}$ of culture (in all instances $P<0.01$ ) indicating that the cells are growing during this period. In order to compare the 'growth rates' of the different tumors $(7,11$ and $40 \mathrm{~g}$ ) and pool I, II and III cells, we calculated for each suspension the number of doublings which took place during the $144 \mathrm{~h}$ culture period. Calculation of the number of doublings was done according to the method described in the Materials and Methods section. Fibroblast contamination and influence of the proliferation of these cells on the 'growth rate' data of the $7315 \mathrm{~b}$ cells can be excluded because fibroblasts (if present) attached to the floor of the wells while the $7315 \mathrm{~b}$ cells did not (see Materials and Mcthods). The cultured $7315 \mathrm{~b}$ could be harvested by removing the culture medium plus cells thereby not collecting the fibroblasts present. We found no statistically significant differences between the tumors of 7,11 and $40 \mathrm{~g}$ with regard to the latter parameter. In addition there were also no major differences between pool I, II and III cells with respect to the number of doublings in $144 \mathrm{~h}$ except for the fact that pool I cells showed in virtually all instances a significantly lower 'growth rate' than pool II and III cells $(P<0.01$ for pool I vs. pool II and III cells). Only the $40 \mathrm{~g}$ tumor pool I and II cells had no different 'growth rates'. Analysis of the viability of pool I, II and III cells at time of plating and after $24 \mathrm{~h}$ of culture revealed that pool I cells always showed a slightly lower viability than pool II and III cells (data not shown). However, between 0 and $24 \mathrm{~h}$ there were no differences in the viability of the cells. Routine light microscopic evaluation of cytospin preparations showed no differences between the original cell suspension and pool I, II and III cell suspensions. In all instances the majority of cells were tumor cells with only a few cells being white blood (host) cells (less than $2 \%$ of the cell population).

Because PRL is the major protein hormone produced by the $7315 \mathrm{~b}$ tumor cells, we also determined the amount of intracellular PRL in the cells of the original cell suspension and of pool I, II and III cells, directly after isolation and after 6 days of culture. Since the number of cells significantly increases during culture and because the 'growth rates' of the pool I, II and III cells showed significant differences, we cxpressed the amount of intracellular PRL as the ratio over DNA. The results are shown in Table 3. Again nu statistically significant differences were observed between the 7,11 and $40 \mathrm{~g}$ tumors and between pool I, II and III cells. The ratio of PRL over DNA after 6 days of culture was in all instances significantly higher (approximately 10 -fold; $P<0.01$ in all instances) than the 
Table 1. Protein content per ng of DNA of Percoll gradient fractions (directly after isolation) of $7315 b$ tumors of increasing weight

\begin{tabular}{lccc}
\hline & $\begin{array}{c}7 g \\
\text { protein/DNA } \\
(\mu \mathrm{g} / \mathrm{ng})\end{array}$ & $\begin{array}{c}11 \mathrm{~g} \\
\text { protein/DNA } \\
(\mu \mathrm{g} / \mathrm{ng})\end{array}$ & $\begin{array}{c}40 \mathrm{~g} \\
\text { protein/DNA } \\
(\boldsymbol{\mu g} / \mathrm{ng})\end{array}$ \\
\hline Original suspension & $348 \pm 32$ & $550 \pm 30$ & $482 \pm 57$ \\
Pool I cells & $534 \pm 37$ & $683 \pm 58$ & $542 \pm 22$ \\
Pool II cells & $426 \pm 17$ & $568 \pm 46$ & $532 \pm 22$ \\
Pool III cells & $441 \pm 35$ & $609 \pm 31$ & $550 \pm 42$ \\
\hline
\end{tabular}

Values in mean \pm S.E.; $n-4$.

Cell suspensions derived from $7315 \mathrm{~b}$ tumors of increasing weight were separated according to differences in their density on continuous Percoll density gradients. Several gradient fractions were pooled in order to obtain pool I, II and III cells (sec also legend to Fig. 1). Aliquots from each suspension containing 25,000 viable cells were analyzed for protein and DNA content.

Table 2. Number of doublings in the original cell suspensions and in the Percoll gradient fractions after 6 days (144 h) of culture

\begin{tabular}{llccc}
\hline $\begin{array}{l}\text { Tumor } \\
\text { weight }\end{array}$ & \multicolumn{1}{c}{ Cell suspension } & $\begin{array}{c}\text { DNA }(t=0 \mathrm{~h}) \\
(\mathrm{ng})\end{array}$ & $\begin{array}{c}\text { DNA }(t=144 \mathrm{~h}) \\
(\mathrm{ng})\end{array}$ & $\begin{array}{c}\text { 'Growth rate' (number of } \\
\text { doublings in 144 h) }\end{array}$ \\
\hline $7 \mathrm{~g}$ & Original suspension & $332 \pm 10$ & $948 \pm 21^{*}$ & $1.51 \pm 0.03$ \\
& Pool I cells & $267 \pm 6$ & $456 \pm 13^{*}$ & $0.77 \pm 0.05$ \\
& Pool II cells & $418 \pm 20$ & $1597 \pm 53^{*}$ & $1.93 \pm 0.05 \dagger^{\dagger}$ \\
& Pool III cells & $386 \pm 23$ & $858 \pm 25^{*}$ & $1.15 \pm 0.04 \dagger$ \\
$11 \mathrm{~g}$ & Original suspension & $293 \pm 6$ & $1007 \pm 51$ & $1.77 \pm 0.07$ \\
& Pool I cells & $203 \pm 12$ & $368 \pm 12^{*}$ & $0.85 \pm 0.05$ \\
& Pool II cells & $270 \pm 4$ & $913 \pm 27^{*}$ & $1.76 \pm 0.04 \dagger$ \\
& Pool III cells & $240 \pm 10$ & $902 \pm 50^{*}$ & $1.89 \pm 0.09 \dagger$ \\
$40 \mathrm{~g}$ & Original suspension & $440 \pm 9$ & $1407 \pm 96^{*}$ & $1.65 \pm 0.10$ \\
& Pool I cells & $300 \pm 7$ & $672 \pm 37^{*}$ & $1.16 \pm 0.08$ \\
& Pool II cells & $360 \pm 19$ & $873 \pm 51^{*}$ & $1.26 \pm 0.09$ \\
& Pool III cells & $309 \pm 17$ & $875 \pm 29^{*}$ & $1.50 \pm 0.05 \dagger$ \\
\hline
\end{tabular}

Cell suspensions derived from $7315 \mathrm{~b}$ tumors of increasing weight were separated on continous Percoll densitv gradients (see legend to Fig. 1). 25,000 cells of the original cell suspension and of the pooled fractions were initially seeded (in six-fold) and subsequently grown for 6 days $(t=144 \mathrm{~h})$ in MEM $+10 \%$ FCS. The DNA content of the cells was determined directly after isolation and after 6 days of culture. 'Growth rates' were calculated as described in the materials and methods section. Values in mean \pm S.E.; $n=+$ for DNA $(t=0 \mathrm{~h})$ and $n=6$ for DNA $(t=144 \mathrm{~h})$.

${ }^{*} P<0.01$ vs. DNA $(t=0 \mathrm{~h}) ; \uparrow P<0.01$ vs. number of doublings in $144 \mathrm{~h}$ of pool I cells; ${ }_{+}^{+} P<0.01 \mathrm{vs}$. number of doublings in $144 \mathrm{~h}$ of pool III cells.

Table 3. Rat prolactin (PRL) content per ng DNA of the original cell suspension and of Percoll gradient fractions of $7315 \mathrm{~b}$ tumors of increasing weight directly after isolation and after 6 days of culture $(\mathrm{t}=144 \mathrm{~h})$

\begin{tabular}{|c|c|c|c|c|c|c|}
\hline & \multicolumn{6}{|c|}{ ratio PRL:DNA (pg:ng) } \\
\hline & $\begin{array}{l}\text { Directly after } \\
\text { isolation }\end{array}$ & $\begin{array}{l}\text { After } 144 \mathrm{~h} \text { of } \\
\text { culture }\end{array}$ & $\begin{array}{l}\text { Directly after } \\
\text { isolation }\end{array}$ & $\begin{array}{c}\text { After } 144 \text { h of } \\
\text { culture }\end{array}$ & $\begin{array}{c}\text { Directly after } \\
\text { isolation }\end{array}$ & $\begin{array}{l}\text { After } 144 \text { h of } \\
\text { culture }\end{array}$ \\
\hline Original suspension & $3.0 \pm 0.5$ & $52.0 \pm 1.8^{*}$ & $3.5 \pm 0.2$ & $40.1 \pm 2.7^{*}$ & $3.7 \pm 0.2$ & $44.0 \perp 1.6^{*}$ \\
\hline Pool I cells & $4.2 \pm 0.6$ & $59.5 \pm 3.5^{*}$ & $4.5 \pm 0.2$ & $41.4 \pm 1.8^{*}$ & $3.5 \pm 0.2$ & $37.4 \pm 3.0^{*}$ \\
\hline Pool II cells & $3.7 \pm 0.1$ & $44.7 \pm 1.9^{*}, \dagger$ & $4.4 \pm 0.1$ & $49.2 \pm 4.5^{*}$ & $2.8 \pm 0.2$ & $36.3 \pm 2.6^{*}$ \\
\hline Pool III cells & $3.3 \pm 0.4$ & $60.0 \pm 2.5^{*}$ & $4.9 \pm 0.6$ & $56.5 \pm 3.5^{*}$ & $3.3 \pm 0.2$ & $27.4 \pm 2.0^{*}$ \\
\hline
\end{tabular}

Values in mean \pm S.E.; ${ }^{*} P<0.01$ vs. PRL:DNA directly after isolation; $\dagger P<0.01$ vs. pool I and III cclls.

See legend to Table 2. 
PRL:DNA ratio directly after isolation indicating that the cells contain virtually no PRL directly after isolation and that they restore their capacity of PRL storage during the 6-day culture period.

Finally, we also determined the responsiveness of the cells in the original cell suspension and in pool I, II and III to $10 \mathrm{nM}$ SMS 201-995. This concentration of the drug had no effect on the growth of the cells (data not shown) but significantly inhibited the amount of intracellular PRL and PRL release by the cells over the 6-day culture period (in all instances $P<0.01$ vs. control PRL release; Fig. 2). There were no statistically significant differences in SMS 201-995 responsiveness between the cell suspension of the 7, 11 and $40 \mathrm{~g}$ tumor and between pool I, II and III cells.

In order to further investigate functional heterogeneity among $7315 \mathrm{~b}$ tumor cells with respect to PRL release, we also studied PRL release by individual cells in unseparated $7315 \mathrm{~b}$ cell suspensions using RHPA. Freshly dispersed $7315 \mathrm{~b}$ cells did not secrete sufficient amounts of PRI to produce plaques in the $24 \mathrm{~h}$ incubation. This was probably due to the low amount of intracellular PRL directly
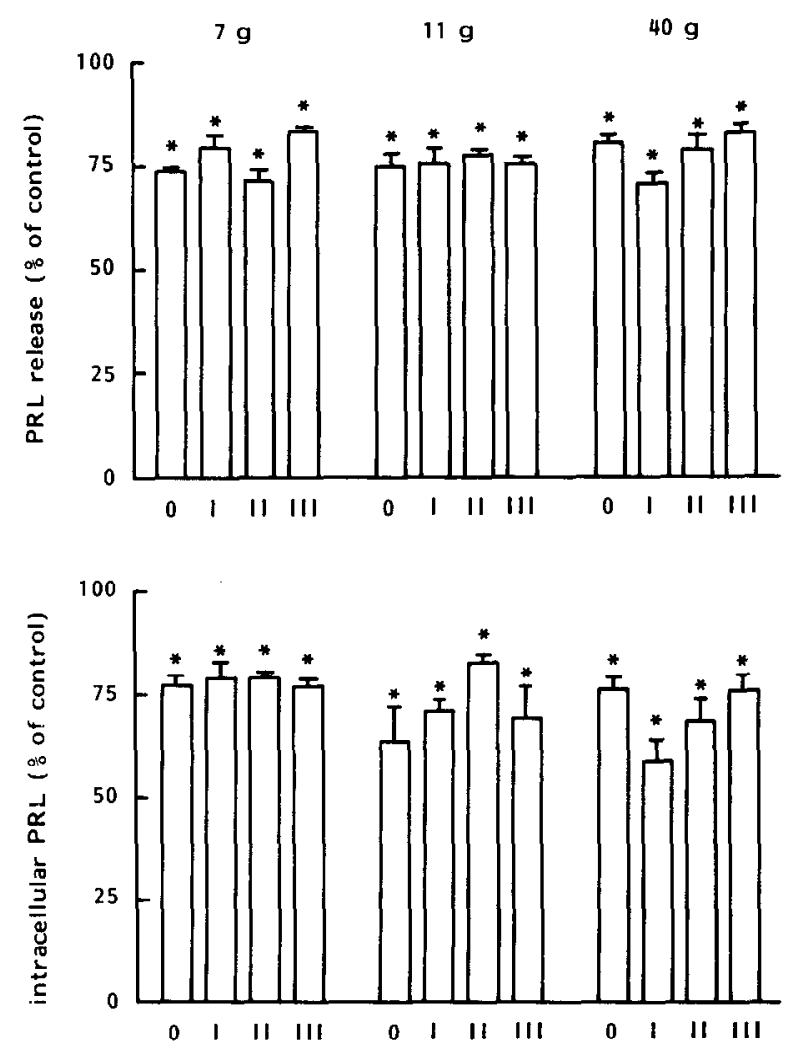

Fig. 2. The effect of $10 \mathrm{nM} S M S$ 201-995 on the release of PRL in 6 days by the original cell suspension $(O)$ and by pool $I, I I$ and $I I$ cells (see legend to Fig. 1) of 7315 b tumors of increasing weight $(7,11$ and $40 \mathrm{~g}$ ). The cells were initially seeded as 25,000 cells per weell (in fourfold) and grow' in MEM $10 \%$ FCS for 6 daps. At the end of the culture period the media were collected and stored at $-20^{\circ} \mathrm{C}$ until analysis of PRL. The values are expressed as the percentage of PRL release in unireated zells. ${ }^{*} P<0.01$ as. control release. after cell isolation (see Table 3). However, using 6day cultures of $7315 \mathrm{~b}$ cells $58 \pm 4 \%$ of the tumor cells formed plaques. Ten nmol/1 SMS 201-995 did not significantly affect the percentage of plaque forming cells $(56 \pm 8 \%)$. However, the drug significantly $(P<0.01$ vs. control without SMS 201-995) inhibitcd the mcan plaque area (mpa) by $47 \%$ (mpa of control cells being $4584 \pm 226 \mu \mathrm{m}^{2}$ and mpa of cells incubated with $10 \mathrm{nmol} / \mathrm{l}$ SMS 201-995 being $2421 \pm 23 \mu \mathrm{m}^{2}$ ). The mpa represents the mean amount of PRL released by 100 cells. Figure 3 shows the frequency distributions of the individual PRL plaque areas produced by unseparated $7315 \mathrm{~b}$ tumor cells in the absence (closed symbols) or in the presence (open symbols) of $10 \mathrm{nmol} / 1 \mathrm{SMS}$ 201-995. The frequency distribution shows, under control conditions, a unimodal mode with a slight skewness toward the larger plaques. In the presence of $10 \mathrm{nmol} / 1 \mathrm{SMS} 201-995$, the frequency distribution shifts toward the smaller plaques. However, the shape of the frequency distribution was not affected by treatment of the cells with SMS 201995 which may indicate that the drug did not preferentially inhibit any population of $7315 \mathrm{~b}$ tumor cells.

\section{DISCUSSION}

It is well established that most murine and human tumors show intrinsic cellular heterogeneity [1]. Until now, however, little is known whether human pituitary tumors or transplantable rat pituitary tumors such as the $\mathrm{GH}_{3}, \mathrm{MtT} / \mathrm{W} 15$ and $7315 \mathrm{a}$ or $\mathrm{b}$ tumors also show functional heterogeneity with regard to cell growth characteristics and/or responsiveness to regulatory hormones or steroids. Three of these experimental tumors have been shown to produce more than one hormone simultaneously. $\mathrm{GH}_{3}$ and $\mathrm{MtT} / \mathrm{W} 15$ tumors contain both single

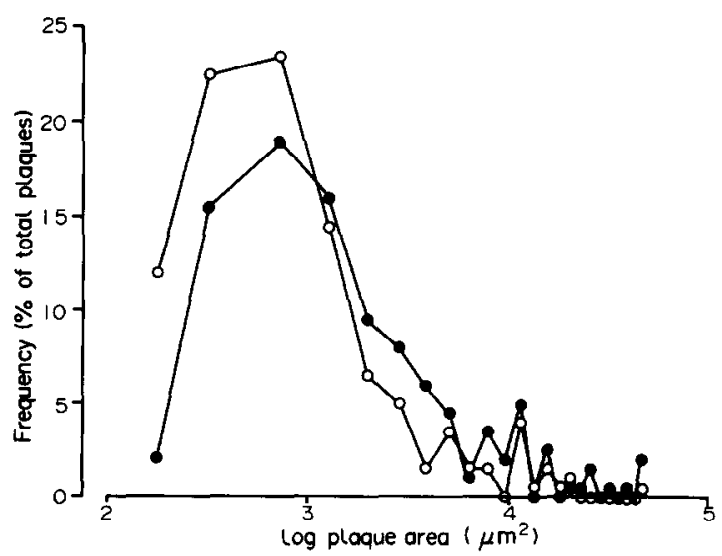

Fig. 3. Frequency distributions of individual PRL. plaque areas by unseparated $7315 b$ rat pituitary tumor cells, in the absence (closed symbols) or in the presence (open symbols) of $10 \mathrm{nmol} / \mathrm{l}$ SMS 201-995. Each point in the frequency distribution represents the mean result from two slides (100 plaques were measured per slide). 
(GH or PRL) and dual hormone secretors (GH and PRL) as determined by the reverse hemolytic plaque assay [5-7], while 7315a tumors produce both PRL and ACTH [8]. Boockfor et al. [6] have demonstrated that cultures of $\mathrm{GH}_{3}$ cells are also functionally heterogeneous. They showed that chronic treatment of cultures of $\mathrm{GH}_{3}$ cells with TRH, estradiol or cortisol caused reciprocal shifts in the proportions of GH and PRL cells present. Although their data were suggestive of interconversion of $\mathrm{GH}$ cells into PRL cells and zice versa they could not preclude the possibility that other processes (such as cell proliferation) were involved. The present study was undertaken in order to evaluate whether functional heterogeneity of cells within the transplantable 'pure' PRL-secreting pituitary tumor $7315 \mathrm{~b}$ exists, with respect to growth rate, PRL production and responsiveness to the somatostatin analog SMS 201-995. We separated freshly dispersed $7315 \mathrm{~b}$ tumor cells derived from tumors of increasing weight on continuous Percoll density gradients, according to differences in their density. The technique of density gradient centrifugation has previously been shown to provide a useful tool for the study of intratumor cell heterogeneity $[16,17]$. The distribution of the $7315 \mathrm{~b}$ cells derived from tumors of increasing weight on the Percoll gradients showed a normal distribution profile with the cells being recovered between a narrow density range. This homogeneous distribution indicates that the cells within the 7315b tumor are physiologically homogeneous. In this respect the observations by Grdina et al. [18] showing that the distribution of tumor cells obtained from density gradient centrifugation reflects the heterogeneity within tumors is of interest. In agreement with the homogeneous profile with respect to the density of the cells we found no differences between the Percoll gradient fractions with respect to protein content per cell, PRL production per cell and responsiveness to the inhibitory effect of the somatostatin analog SMS 201-995. In addition, we found no differences between tumors of increasing weight $(7,11$ and $40 \mathrm{~g})$ with respect to these parameters and with respect to the growth rates of the tumor cells in vitro. Therefore, it can be concluded that the $7315 \mathrm{~b}$ transplantable PRL-secreting pituitary tumor is homogeneous with regard to its cellular composition and that growth of $7315 \mathrm{~b}$ tumors in vivo does not lead to the induction of heterogeneous subpopulations as has been described for most human and murine solid tumors [1]. The lack of heterogeneity between the gradient fractions in responsiveness to the somatostatin analog SMS 201-995 may exclude clonal selection of somatustatin-unresponsive cells leading to "escape' of the tumor from the tumor growth-inhibitory effect of this drug as has been described previously $[8 \mid$.
Since the $7315 \mathrm{~b}$ pituitary tumor cells do not store large amounts of PRL, the method of density gradient separation may not have been an appropriate method for the study of functional heterogeneity among $7315 \mathrm{~b}$ tumor cells with respect to PRI. release. Therefore, we also used an alternate technique, RHPA, which has been previously shown to detect functional subtypes of hormone-secreting cells in unseparated, normal rat anterior pituitary cell suspensions [19-22]. The results of our experiments using the RHPA for the detection of PRI, release by individual $7315 \mathrm{~b}$ cells basically confirmed our cell separation data. In agreement with the latter data we found no evidence for a differential responsiveness to SMS 201-995 among cells of the 7315 b tumor. Only with respect to basal PRI. relcase have we demonstrated that there was at minor population of adenoma cells secreting a high amount of PRL.

The only difference that was observed in our study between the Percoll gradient fractions was a slightly lower growth rate of the cells in the gradient fraction with the lowest density. It is unlikcly that this particular fraction represents a subpopulation of tumor cells in a non-proliferating or quiescent state [23,24] caused by nutrient deprivation of the tumor cells in vivo. First, studies using density gradient centrifugation of murine fibrosarcoma cells have previously shown that these particular subpopulations are recovered in the high density region of density gradients $[16,17]$, while secondly we observed no shifts in the density distribution profile of tumor cells derived from tumors of increasing weight and no differences between these tumors with respect to their growth rates in ritro. Therefore. the most likely explanation for the lower growth rate of the low density fraction is a lower viability of the cells (or part of the cells) in this gradient fraction related to a limited life-span of the cells. In agreement with this is our observation that this fraction had a slightly lower viability than the higher density fractions.

In conclusion our study demonstrates that the transplantable PRL-secreting rat pituitary tumor $7315 \mathrm{~b}$ consists of a homogeneous cell population as measured by density distribution profile, protein content of cells, growth rates and responsiveness to the somatostatin analog SMS 201-995. ()nly with respect to PRL production per cell may there be a small fraction of cells within the tumor cell population secreting a high amount of PRL. Whether this tumor homogencity is representative for human pituitary tumors in general remains to be estatlished.

Acknowledgements-This study was supported by grants from the Willem Kroger Foundation, Rotterdam and the Dutch Cancer Foundation. 


\section{REFERENCES}

1. Leith JT, Dexter DL. Mammalian Tumor Cell Heterogeneity. Boca Raton, CRC Press, 1980.

2. Trouillas J, Girod C, Sassolas G, Claustrat B. Immunocytochemistry, what does it add to clinical management? In: Landolt AM, Heitz PU, Zapf J, Giraud E, del Pozo E, eds. Advances in Pituitary Adenoma Research. New York, Pergamon Press, 1987, Vol. 69, 11-20.

3. Melmed S, Braunstein GD, Horvath E, Ezrin C, Kovacs K. Pathophysiology of acromegaly. Endocrin Rev 1983, 4, 271-290.

4. Lloyd RV, Anagnostou D, Cano M, Barkan AL, Chandler WF. Analysis of mammosomatotropic cells in normal and neoplastic human pituitary tissues by the reverse hemolytic plaque assay and immunocy tochemisty. J Clin Endocrinol Metabol 1988, 66, 1103-1110.

5. Lloyd RV. Analysis of prolactin and growth hormone production in the MtT/F4 transplantable pituitary tumor by the reverse hemolytic plaque assay. Am J Pathol 1987, 129, $441-447$.

6. Boockfor FR, Hoeffler JP, Frawley LS. Cultures of $\mathrm{GH}_{3}$ cells are functionally heterogeneous: thyrotropin-releasing hormone, estradiol and cortisol cause reciprocal shifts in the proportions of growth hormone and prolactin secretors. Endocrinology 1985, 117, 418-420.

7. Boockfor FR, Schware LK. Cultures of $\mathrm{GH}_{3}$ cells contain both single and dual hormone secretors. Endocrinology 1988, 112, 762-764.

8. Lamberts SWJ, Reubi JC, Uitterlinden P, Zuyderwijk J, van den Werff P, van Hal P. Studies on the mechanism of action of the inhibitory effect of the somatostatin analog SMS 201-995 on the growth of the prolactin/adrenocorticotropin-secreting pituitary tumor 7315a. Endocrinology 1986, 118, 2188-2194.

9. Snyder G, Hymer WC, Snyder J. Functional heterogeneity in somatotrophs isolated from the rat anterior pituitary. Endocrinology 1977, 101, 788-799.

10. Smith PF, Luque EH, Neill JD. Detection and measurement of secretion from neuroendocrine cells using the reverse hemolytic plaque assay. Methods Enzymology 1986, 124, 443-465.

11. Lamberts SWJ, van Koetsveld P, Verleun T. Prolactin release-inhibitory effects of progesterone, megestrol acetate, and mifepristone (Ru 38486 ) by cultured rat pituitary tumor cells. Cancer Res 1987, 47, 3667-3671.

12. Leong DA, Lau SK, Sinha YN, Kaiser DL, Thorner MO. Enumeration of lactotropes and somatotropes among male and female pituitary cells in culture: evidence in favor of a mammosomatotrope subpopulation in the rat. Endocrinology 1985, 116, 1371-1378.

13. Downs TR, Wilfinger WW. Fluorometric quantification of DNA in cells and tissue. Anal Biochem 1983, 131, 538-547.

14. Snedecor GW, Cochran WG. Statistical Methods. Ames, Iowa State University Press, 1980, 235-237.

15. Patterson MK. Measurement of growth and viability of cells in culture. Methods Enzymol 1979, LVIII, 141-152.

16. Sidgestad CP, Grdina DJ. Separation of murine fibrosarcoma cells by density centrifugation following tritiated thymidine labelling. Radiat Res (Abstract) 1978, 74, 542.

17. Sidgestad CP, Grdina DJ. Density rentrifugation of murine fibrosarcoma cells following in situ labelling with tritiated thymidine. Cell Tissue Kinet 1981, 14, 589-600.

18. Grdina DJ, Milas L, Mason KA, Withers HR. Separation of cells from a fibrosarcoma in renografin density gradients. J Natl Cancer Inst 1974, 52, 253-257.

19. Frawley LS, Neill JD. A reverse hemolytic plaque assay for microscopic visualization of growth hormone release from individual cells: evidence for somatotrope heterogeneity. Neuroendocrinology 1984, 39, 484-487.

20. Hoeffler JP, Hicks SA, Frawley LS. Existence of somatotrope subpopulations which are differentially responsive to insulin-like growth factor I and somatostatin. Endocrinology $1987,120,1936-1941$.

21. Boockfor FR, Hoeffler JP, Frawley LS. Analysis by plaque assays of GH and prolactin release from individual cells in cultures of male pituitaries. Neuroendocrinology 1986, 42, $64-70$.

22. Luque EII, Munoz de Toro M, Smith PH, Ncill JD. Subpopulations of lactotropcs detected with the reverse hemolytic plaque assay show differential responsiveness to dopamine. Endocrinology 1986, 118, 2120-2124.

23. Wallen CA, Higashikubo R, Dethlefsen LA.. Murine mammary tumour cells in vitro. I. The development of a quiescent state. Cell Tissue Kinet 1984, 17, 65-77.

24. Wallen CA, Higashikubo R, Dethlefsen LA. Murine mammary tumour cells. II. Recruitment of quiescent cells. Cell Tissue Kinet. 1984, 17, 79-89. 